\title{
Solidarity economy and agricultural cooperatives: The experience of the Brazilian Landless Rural Workers Movement
}

\author{
Marie-Josée Massicotte* \\ School of Political Studies, Université d'Ottawa/University of Ottawa
}

Submitted August 28, 2013 / Revised March 3 and April 23, 2014 / Accepted April 24, 2014 /

Published online June 23, 2014

Citation: Massicotte, M.-J. (2014). Solidarity economy and agricultural cooperatives: The experience of the Brazilian Landless Rural Workers Movement. Journal of Agriculture, Food Systems, and Community Development, 4(3), 155-176. http://dx.doi.org/10.5304/jafscd.2014.043.011

Copyright (C) 2014 by New Leaf Associates, Inc.

\begin{abstract}
Based on field research in southern Brazil, this paper examines successful experiences of encampment, and especially of two agricultural cooperatives of the Landless Rural Workers Movement (MST) as part of the solidarity economy. These co-ops exemplified collective searches for better living conditions to respond to people's needs and hopes, beside and beyond the market economy. The paper thus explores (1) community
\end{abstract}

Note: This article draws from a joint presentation and article (Massicotte \& Marques, 2012) with Dan F. Marques, PhD candidate at the University of Ottawa, at the workshop on Political Economy and Political Ecology held at the Canadian Political Science Association Conference in Edmonton, Canada, in 2012. Translation of all quotations in this paper are by the author or by Dan F. Marques, research assistant.

* Marie-Josée Massicotte, Associate Professor, School of Political Studies, FSS 7044/Faculté des sciences sociales (FSS) 7044; 120, rue Université; Université d'Ottawa/ University of Ottawa; Ottawa, Ontario K1N 6N5 Canada; +1-613-562-5800, poste 2732; massicot@uOttawa.ca

Author's website: http://www.massicotteresearch.com dynamics and movement-building among MST participants as they interact with one another and are shaped by daily practices in their collective struggle for land access and justice; (2) how they foster alternative imaginaries (vision, hope, projects), forms of production, and social reproduction that nurture greater autonomy, solidarity, cooperation, and democratic participation; and (3) how various forms of cooperation allow MST participants to appropriate, defy and transform dominant norms and practices in their everyday lives. The latter process is crucial for researchers and activists interested in social change since these forces are contributing to opening up spaces that allow the emergence of new norms and values, intertwined with new practices and ways of being in the making, despite existing obstacles and challenges.

\section{Keywords}

agricultural cooperatives, agroecology, Brazil, community economies, cooperation, food studies, MST, peasant movements, social justice, solidarity economy 


\section{Introduction}

In Latin America, the solidarity economy is organized around a variety of experiences, partly in response to the hardships created by neoliberalism since the 1980s, and partly building on values of mutual help, various forms of exchanges, and the creativity of peoples (Gaiger, 2007; Souza da Silva \& Feijó Fagundes, 2011). Such values and experiences are not equally shared or maintained, however, by all rural families and communities. They are continually transformed through interactions with other values and practices (e.g., individualism, competitiveness), and their proponents are facing multiple challenges and obstacles. The solidarity economy continues to be depicted and perceived as a fragile, marginal, and/or temporary survival strategy (Mourão Vieira, 2005, p.11), due in part to the adoption of a set of policies supporting an industrial model of specialized monocultures. In this context, it is crucial for researchers and activists interested in social change and justice to explore specific cases where communities have succeeded in sustaining cooperation, solidarity, and autonomous forms of governance. These forces are opening up spaces for alternative norms and practices, based on different values and sociopolitical projects, as well as new ways of imagining life and modes of interactions within communities (Wittman, 2007). These norms and practices are already playing a critical role in shaping societies, even as they remain largely invisible and fragile (de Sousa Santos, 2006, 2010; Gibson-Graham, 2006).

This paper focuses on encampment experiences, and especially on two successful cases of agricultural production cooperatives of the Landless Rural Workers Movement (MST, its Portuguese acronym) in the southern region of Brazil. ${ }^{1}$

\footnotetext{
${ }^{1}$ Encampment (acampamento) refers to the site and period during which landless individuals are occupying a piece of land - usually in very precarious conditions, facing for example, food, weather and physical insecurities — and asking the Brazilian governement to proceed with its expropriation and distribution, as required by articles 184 and 186 of the 1988 Constitution, when land does not fulfill its social function. The assentamento, or settlement, is the site legally allocated to a group of farming families where they can begin to access credit and other resources to move toward more stability. (For a good and accessible introduction to the MST, see Branford
}

The MST is one of the most significant mass movements in Latin America, in term of membership, longevity, and sociopolitical influence. It was officially launched in 1984 following a series of isolated land occupations toward the end of the 1970s, when the military regime became increasingly contested. These rural struggles were reactions to land concentration and the hardships faced by poor rural populations linked to the modernization project that promoted the development of agribusinesses and hydroelectric megadams. Thousands of farming families have been pushed toward industrializing and now overcrowded urban centers, without many employment opportunities. In fact, since the colonization of Brazil, fertile land has remained highly concentrated among a handful of mostly white male landowners, drastically deepening the crises in the countryside (Wright, A. L., \& Wolford, 2003; Stédile \& Fernandes, 1999). This helps to explain why Brazil still has one of the most inequal income distributions in the world (Instituto Brasileiro de Geografia e Estatística [IBGE], 2013). Yet it is only one side of the story.

The two MST agricultural cooperatives under study here exemplify another side: that of collective searches for better living conditions that rely on alternative economies and mutual help. They explicitly challenge the dominant agribusiness model by appropriating and subverting the dominant discourse on what is possible and most effective; they defy the capitalist model and create innovative techniques (see de Certeau's "arts of doing," 1990) based on different norms and "real utopias" (Wright, E. O., 2010). The paper thus explores: (1) community dynamics among MST participants as they interact and are shaped by daily practices in their collective struggles for land access and justice; (2) how they foster alternative imaginaries (vision, hope, projects), forms of production, and social reproduction that nurture greater autonomy, solidarity, cooperation, and democratic participation; and (3) how various forms of cooperation allow MST participants to appropriate, defy, and transform dominant norms and practices in their everyday lives.

\& Rocha, 2002; Stédile \& Fernandes, 1999; Wright \& Wolford, 2003.) 


\section{Methodology}

This qualitative analysis is based on field research conducted between 2005 and 2011, mostly in southern Brazil. It relies on document analysis of primary and secondary literature (MST websites, articles, documentaries, pamphlets, and symbols, as well as governmental documents, mass media coverage, and scholarly books and articles) to identify and analyze the norms, values, and dynamics of MST communities that orient their everyday struggles for social change and justice. This was complemented by open-ended, semidirected interviews (lasting 40 to 140 minutes), extensive informal discussions, and participatory observation during multiple visits to encampments and settlements of the MST, as well as at the MST national secretariat, two MST state secretariats, the MST schools Florestan Fernandes and Milton Santos, and the Escola Latino Americana de Agroecología of La Vía Campesina (Latin American School of Agroecology, concept to be defined below). I also attended the 10th Jornada de Agroecologia, June 22-25, 2011, in Londrina, Paraná, where over 4,000 participants - peasants, students, landless, workers, women, members of environmental movements and nongovernmental organizations (NGOs), academics and international allies — joined together to promote agroecological farming practices, share experiences, organize workshops, and barter seeds. I interviewed over 50 individuals, including MST national, state, and community leaders, as well as regular members and co-op associates, most of them from the states of Paraná, Rio Grande do Sul, São Paulo, and Santa Catarina, where the MST's roots are and where many of the movement's cooperatives are located. I also conducted interviews with six analysts and allies of the MST who could provide important background information and historical insights. As a foreign woman researcher from the global north, I was acutely aware of my privileged position, power, and gender relations, as well as cultural and linguistic limitations. Nonetheless, the multiple visits and methods were useful to build trust and to better understand the context and conditions that contribute to successful solidarity experiences in food production cooperatives. I also relied on Brazilian research assistants to help with some interviews, transcriptions, and translations.

This paper specifically examines two case studies. The first, the Cooperativa de Produção Agropecuária União do Oeste (Cooperunião), is an agricultural co-op created in 1990 and located in the state of Santa Catarina, very close to the Argentinian border, in the municipality of Dionisio Cerqueira (see Map 1). Among the first co-ops of the MST, the Cooperunião is economically successful and self-sufficient. Today, all 60 families of the settlement, covering 2,965 acres $(1,200$ hectares), are part of the Cooperunião. They produce collectively everything they need to ensure their subsistence, including poultry, fish, corn, milk, honey, fruits, vegetables, and tea. Their most important output is conventionally produced poultry, which has expanded to the point that more than 400 small farming families from 15 assentamentos of the region are now associated with the coop. The latter is controlling the whole production process, from animal feed and manure management to distribution and marketing, with a slaughtering capacity soon to reach 2,000 chickens per hour ${ }^{2}$ (email communication with a member of the COOPAN, February 23, 2014; anonymous interview, Ministério do Desenvolvimento Agrário, 2010). The second agricultural co-op to be analyzed is the Cooperativa de Produça Agropecuaria Nova Santa Rita Ltda (Coopan), created in May 1994, only a month after the settlement was established for 100 landless families on land covering 5,360 acres (2,169 ha). The Coopan produces mostly organic, agroecological rice, and conventional pork. It is located approximately 19 miles $(30 \mathrm{~km})$ north of Porto Alegre, the capital city of the state of Rio Grande do Sul (see Map 1).

It should be noted that these two cooperatives are neither representative nor easily replicable cases. Other co-ops are fragile or have failed in seeking to implement similar norms and practices in Brazil and elsewhere (Diniz \& Gilbert, 2013; Vergara-

\footnotetext{
${ }^{2}$ See more at the Ministério do Desenvolvimento Agrário (MDA) site: http://www.mda.gov.br/portalmda/noticias/ cooperuni $\%$ C $3 \% \mathrm{~A} 30-$ amplia-produ $\% \mathrm{C} 3 \% \mathrm{~A} 7 \% \mathrm{C} 3 \% \mathrm{~A} 3 \mathrm{o}$-defrango-em-santa-catarina; and at the Censo Agropecuário 2006 at the Instituto Brasileiro de Geografia e Estatística (IBGE) website: http://www.ibge.gov.br/home/estatistica/ economia/agropecuaria/censoagro/2006/agropecuario.pdf
} 


\section{Map 1. Locations of Study Areas}

Both study locations are in the southern region of Brazil. The Cooperunião is in the municipality of Dionisio Cerqueira (in red), state of Santa Catarina (next to the Argentinian border at left), and the Coopan is in the municipality of Nova Santa Rita (also in red), very close to the capital city of Porto Alegre, state of Rio Grande do Sul.

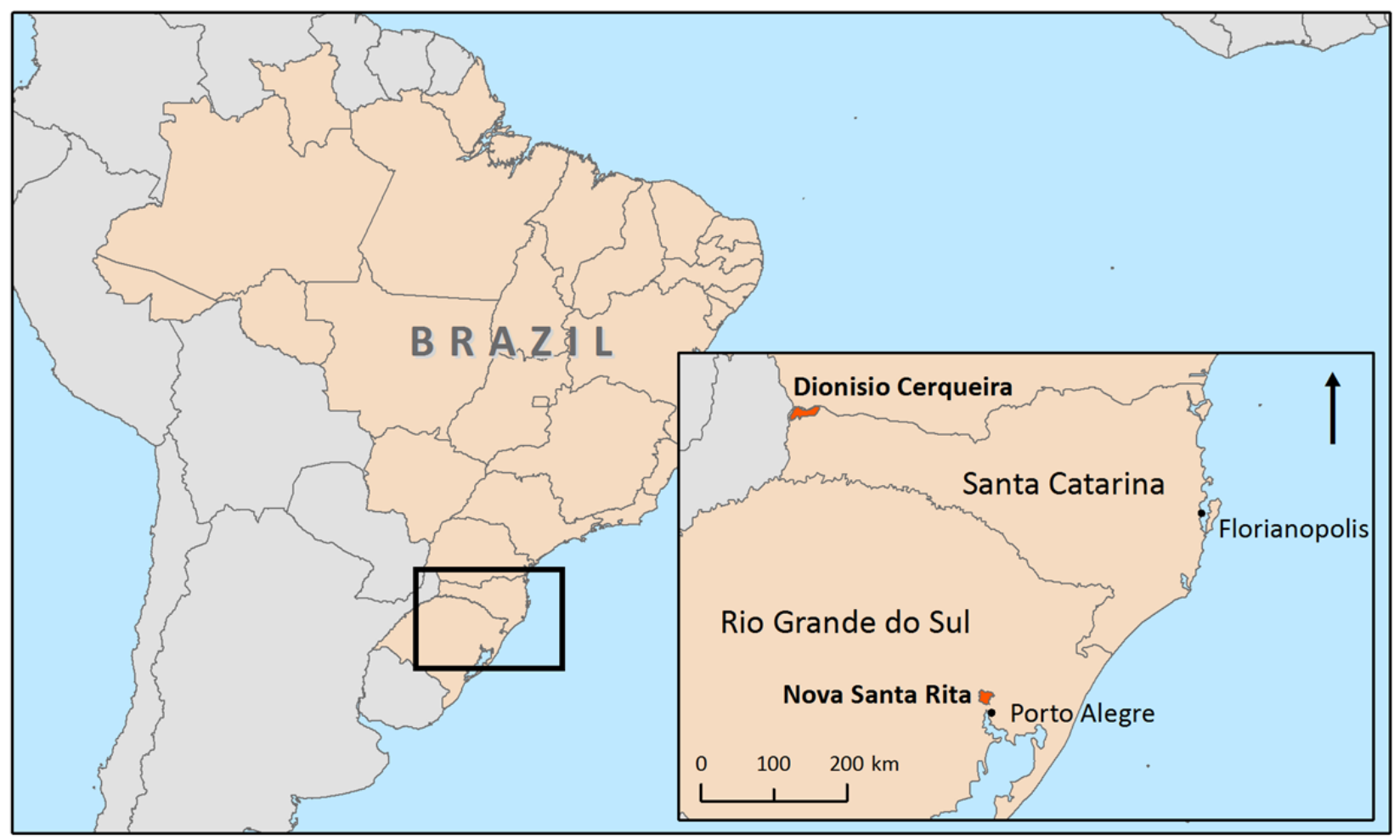

Source: Instituto Brasileiro de Geografia e Estatística. (2007). Digital Municipal Mesh. Map created by Sarah Simpkin.

Camus, 2009). However, it remains essential to examine and make visible those emerging, successful experiences so as to obtain a better understanding of the ways in which social change is actually happening in specific cultural, political, and socioeconomic contexts.

\section{Conceptual Framework: The Solidarity Economy and Everyday Forms of Peasant Resistance in Southern Brazil ${ }^{3}$}

Looking back a few decades, one begins to realize how the development and modernization agenda promoted mostly by Western-based "experts"

\footnotetext{
${ }^{3}$ Borrowing from James Scott (1985), I am using the concept "peasant" since the MST, as a key member of La Via Campesina (The Peasant Way), has adopted this language to refer to small and medium-scale farmers who are living on and cultivating the land.
}

ended up marginalizing — but never erasing completely - the solidarity economy and reciprocity practices, north and south (Escobar, 2004; McMichael, 2004; Rist, 2008). This has been reinforced, in Brazil as elsewhere, by the Green Revolution and its technology packages promoting an agriculture that is capital- and oil-intensive, but reportedly more "efficient" and productive. In implementing its practices, many family farmers have been displaced, put in precarious positions, or made to believe that they need to adopt marketcentered strategies and grow their farms in order to survive and compete. Even among the early MST settlements, most small farmers sought to follow the industrial path, introducing chemical inputs and favoring monocultures (e.g., sugar cane, cattle). However, after noticing the pervasive impacts of this model on the land and people's health, and also on indebtedness and household subsistence, 
various communities began to look for alternative models of production, work, and social reproduction that challenge dominant norms and practices in their everyday activities, based on an alternative vision of society.

The solidarity economy is one such alternative, re-emerging as a way to respond to people's needs and hopes, beside and beyond the market economy, or at least partly sidestepping market exchanges and the circuits of capital (Fiorentin, 2006; Lemaître \& Helmsing 2012; Mourão Vieira, 2005). In Latin America, the participants in the solidarity economy come from various backgrounds and sectors; many are either excluded from the formal market economy or their salary is insufficient to live a decent life and support themselves and their families (Marañón, \& López, 2010). ${ }^{4}$ These experiences have the potential of repoliticizing the economy and creating new forms of socioeconomic interaction, as well as deepening democratic and solidarity norms and practices. Yet few analyses have linked MST agricultural cooperatives to the solidarity economy literature (although for an exception see Mourão Vieira, 2013), or to alternative agri-food networks and the solidarity economy as movements (visit http://www.faanweb.eu/ for an example of alternative agri-food networks). This study begins to fill these gaps by highlighting the ways in which the MST is sharing values and practices promoted by the solidarity economy, while providing an alternative economic model that defies some elements of the capitalist market economy, and that goes beyond the European or North American examples of the social and solidarity economy. Moreover, even among MST's leadership, ${ }^{5}$ few analysts have identified agricultural coops as participating in the solidarity economy, nor have they explored to what extent such economic

\footnotetext{
${ }^{4}$ We can think of the Argentinian workers who after the 2001 financial debacle organized to regain control of bankrupt factories as workers' co-ops and to ensure their subsistence. Nonetheless, work and income generation remain key objectives for the actors under study here.

${ }^{5}$ This is based on field research notes, conversations and interviews with MST members and researchers, as well as ongoing analysis of information provided by the MST and its allies (websites, journal and magazine articles, public documents, etc.).
}

alternatives contribute to mobilizing activists and sustaining the movement among marginalized communities.

In this highly populated country, rich in cultural and natural resources, just under 15 percent of the population lived in the countryside as of 2010 (IBGE, 2013, p. 71); however, about 51 percent of the poverty (less than $\mathrm{R} \$ 2$ a day) is concentrated among the rural population. Nonetheless, small-scale family agriculture creates most rural employment (about 84 percent as of 2006) and "accounts for about 70 per cent of the country's food production and a significant share of food exports" (International Fund for Agricultural Development [IFAD], n.d.; Russo, 2012). On the other hand, fewer than 3 percent of large landholders (greater than 2,470 acres or 1,000 hectares) own more than 43 percent of all cultivated farmland in Brazil, whereas a great number of smallholders with less than 25 acres or 10 hectares occupy around 2.7 percent of all rural settlements (Russo, 2012).

Following Quijano (2008), Gaiger (2007), and Corragio (2011), this study refers to the solidarity economy concept, not so much due to its legal characteristics or organizational structure, but to highlight key principles that work to foster a set of solidarity practices, including autonomy, cooperation, equality seeking, co-responsibility, reciprocity, and collective forms of governance and decisionmaking that contribute to build capacity and strengthen communities (Massicotte \& Marques, 2012). These elements are not equally shared nor systematically implemented in every community under study. Nonetheless, they are central to processes aimed at deepening democratic practices, social justice, and solidarity practices. These ideals guide most rural community projects of the MST. The two cases under investigation here both have a history of practices and explicit efforts to enact at least some of these principles. "Success stories" were chosen also because they better enable us to analyze the conditions and mechanisms by which these co-ops were able to translate principles into daily practices. This is informed by a normative stance, to propose not specific recommendations, policies, or actions, but rather a shared sense that these types of innovations and changes are neces- 
sary to move toward a more just and ecologically sustainable society and agriculture.

It is thus essential to better understand how specific actors have already been able to consolidate alternative norms and practices in particular contexts. As the work of Michel de Certeau (1990) suggests, this paper explores the "appropriation" that everyday actors make of mainstream representations, which implies a process of re-production of meaning that may or may not reflect the initial norm in circulation. Indeed, peasants, landless laborers, and other marginalized actors are not passive receptors. They create their own ways of imagining community life and produce new meanings and practices. Their proactive behavior may succeed in distorting normative constraints, tactically twisting and manipulating them into more positive outcomes that better fit their priorities (de Certeau, 1990; Scott, 1985). ${ }^{6}$ Analyses such as that presented here allow us to understand not only some of the conditions under which resistance emerges but also how participants attribute meaning to their own everyday struggles.

Political economist Karl Polanyi is another important scholar who studied resistance forces and different economic models. He has reminded us that societies are not only organized and integrated through market relations, but also through redistribution (via the modern state, the church, feudal systems, etc.) and reciprocity (exchange of services, care, labor, land, seeds, as well as more symbolic aspects such as honor, respect, emotional support, etc.). Denouncing the attempts to transform land, labor, and money into commodities for the "well functioning of a market economy" and "human prosperity," Polanyi demonstrated that the attempts to separate, or "disembed," the economy from society were far from natural or automatic, requiring rather violent forms of intervention (enclosure, work houses, Poor Laws, etc., see (Polanyi, 1944). The very efforts by some to create a so-called self-regulated market have led to a countermovement from society to protect itself. Polanyi argued that such a separation of the

\footnotetext{
${ }^{6}$ Thanks to Dan F. Marques for this insight. For similar arguments but drawing from the work of Arendt and decolonial thought, see Icaza and Vázquez, 2013.
}

economic and the social spheres could never be completed except by destroying the very fabric of society and the environment, which is also essential for human survival. Indeed, the raison d'etre of the economy was first thought of as the sphere of activities for providing what is necessary for the well-being of the individual or the family unit. In this sense, the solidarity economy is a rediscovered form of social organization that communities across the globe are promoting in order to nurture economic relations that respond first and foremost to people's needs and aspirations.

Pushing the argument of the diversity of economic relations and their continued embeddedness in contemporary societies, the Community Economies Research Network (http://www. communityeconomies.org/) and Gibson-Graham's (2006) work offer a feminist critique of political economic approaches that insists on theorizing, making visible, and enacting alternative visions of economy that are usually discredited and/or marginalized by dominant discourses. Their analyses show that alternative economic practices are used by thousands of people in different sectors and regions on a daily basis as the main source of revenue and subsistence. These alternatives include the solidarity economy and "community economies," the advocates of which promote the main principles also highlighted above. The community economies scholars also use the concepts of "diverse economies" and "alternative economies" in order to highlight the fact that economies are always diverse and always under construction. Their works thus seek to make visible the multiplicity of economic practices that exist beside and beyond the capitalocentric forms of market exchanges, an objective also pursued in this paper.

Two additional concepts need to be clarified. In Latin America, "agroecology" refers to a science and a set of principles. As such, it is an ideal to attain and an alternative model of small scale, diversified agriculture that seeks to avoid agrotoxins and genetically modified organisms (GMOs), that is economically and environmentally sustainable, and that produces healthy and culturally appropriate food primarily for small producers and local markets, thus challenging "neoliberal modern- 
ization policies" (Altieri \& Toledo, 2011, p. 587). It goes beyond organic farming by rejecting organic monocultures; it promotes a holistic view that values technical training for production, but also social reproduction and the strengthening of peasant and rural worker movements. Its advocates value local knowledges and their socialization so that a greater number of small producers can benefit from such knowledges and improve each other's socio-ecological techniques and productivity, respecting the lifecycles of both human beings and ecosystems (Altieri \& Toledo, 2011; Gliessman, 2001). In Brazil, "food sovereignty" is promoted mostly through agroecology principles. To promote and implement agroecological practices during the 4th National Congress of the MST in 2000, the 11,000 delegates collectively decided to incorporate agroecology into all their education and training programs, from elementary school curriculum to political leadership courses and university-level degrees dedicated to agroecology (Hadich \& Tardin, 2009; Massicotte, 2014; interviews, 2011).

The following analysis thus examines existing practices and the collective processes of appropriation of economic and reproductive activities that rely on solidarity among small food producers who value another form of living together and who seek ways to promote greater justice and autonomy while respecting ecosystem cycles in specific cultural, political and ecological territories (Quijano, 2008). These principles are similar to the concept of buen vivir, or living well, promoted by indigenous communities, especially in the Andes (Gutiérrez Escobar, 2011). The solidarity economy thus refers to an explicitly sociopolitical and emancipatory project designed and appropriated by core participants to open up opportunities and to foster greater equality, democracy, and cooperation among themselves. ${ }^{7}$ This paper examines concrete experiences

\footnotetext{
${ }^{7}$ As noted, not all solidarity economy projects fit into this definition, but the cases under study respond to these criteria. I also avoid free association and collective ownership of the means of production as principles because adoption of the cooperative model was not necessarily the preferred economic option. Some participants felt pressure to join the co-ops, and most MST co-ops chose not to adopt collective work, but they consider the co-op as an alternative, emancipatory project.
}

where individuals engage with and participate collectively in innovative initiatives to secure their subsistence through alternative production and reproduction models, thus succeeding in improving their common well-being (differently defined and evolving through experience). The conclusion briefly discusses some of the obstacles and opportunities that sustain and limit the potential for consolidating and diffusing such alternative solidarity economies and communities.

\section{Encampments: A Privileged Space of Politicization and Everyday Collaborative Exchanges}

This section analyses everyday practices and values of participants in MST encampments and cooperatives that challenge dominant norms and ways of living, thus contributing to the development of alternative economies based on solidarity principles. In order to speak to this issue, I first need to explain the relevant practices of the MST. This landless movement emerged in the early 1980s in a context of rebellion in Brazil, a country that was still under a military regime, which was losing control over a population fighting for change, democracy, and justice. For decades there had been demands for agrarian reform, but the dictatorship had emerged partly in response to a modest attempt by President Joao Goulart in March 1964 to redistribute land (Konder Comparato, 2004). In a society with dire rates of poverty, discrimination (both race and gender-based), and startling inequalities between the richest few and the masses of poor people, land occupations in rural areas reemerged in the early 1980s as a prominent way to resist and survive.

When the MST was officially created in 1984, the objective was to join forces across the immense national territory to call for justice that, in the eyes of those commonly experiencing exploitation, requires democratizing the access to land. One of the main slogans reveals much about their tactics: "Occupy, resist, produce." Through direct action, the MST leadership invites landless people to collectively occupy underutilized land. They use moral justification, or in de Certeau's words, "a style of moral resistance" in reaction to injustice and colonial abuse, as well as legal and constitutional arguments (redistribution to fulfil the "social 
function" of the land and contestation of land titles fraudulently acquired) as tactical tools to demand redistribution and gain legal titles (Wright, A. L., \& Wolford, 2003). However, the acquisition of land titles often takes much patience, political pressure and struggle in encampments.

In the meantime, the families organize and resist. As Nashieli Rangel Loera aptly highlights, "encampment time" is essential in politicizing participants and promoting greater activism, political training, and leadership building. Indeed, the months and years of everyday sacrifice, suffering, and commitment to the struggle required to obtain access to land symbolize key social status markers to gain respect within the MST (Brandford \& Rocha, 2002; Rangel Loera, 2010; Stédile \& Mançano Fernandes, 1999/2005. From the initial moment of occupation, when women are usually at the forefront in their shared struggle for land and dignity with their male counterparts, through the organization of daily life with participants, who generally do not know each other but need to work together on a daily basis to meet their needs (e.g., access to food, clean water, security) and establish common norms for the emerging community, the encampments become privileged spaces of politicization, resistance, mutual help, and friendship building.

The experiment of a community put in motion, by choice and by necessity, allows for the institution of alternative norms and practices, such as solidarity and reciprocity. In turn, these norms and practices bind people together, not only through a common goal (such as land access), but also through establishing collectively what a just community should look like, in principle and in practice. Each experience of encampment remains unique, and the process of organizing is in itself quite stressful and prone to confrontations and constraints vis-à-vis outside forces and among participants themselves, despite their shared social marginalization. The harshness of everyday life in camps (fear, hunger, cold, rain and mud, burning hot days, etc.) often discourages some participants or family members, dividing people and diminishing the number of bodies to defend the "conquered" territory. In this sense, one needs to be careful not to romanticize these experiments nor take for granted that efforts in nurturing mutual trust, solidarity, and cooperation will eventually succeed (Massicotte \& Marques, 2012). Some acampamentos failed to consolidate and gain formal titles. And whereas some participants may occupy other territories until they finally gain land titles, others leave the MST and abandon the struggle, or join other popular organizations (Rangel Loera, 2010).

Different styles of leadership emerging among those occupying the land can help or hinder the social integration process and the sense of solidarity. Some are charismatic leaders, others are respected for their long farming experience or formal education, and yet others bring in particularly useful skills in communicating and in reconciling participants who have divergent views or interests. For instance, during a field research trip in May and June 2009, one encampment was fractured mostly due to the rejection of the leadership style of a strongman in the state of São Paulo; at the same time, another was flourishing and had recently gained legal title, based on the multiple involvements of a group of mostly women promoting political activism, reciprocity, and solidarity (field research notes and interviews with MST members and allies, Irma Alberta settlement, MST National Secretariat in São Paulo, 2005, 2009).

Hence, identities and ways of being are transformed through collective participation as subjects making their own history, sharing new and often positive experiences, and deliberating and dealing with tensions and conflicts. The social references that participants had prior to land occupations are sometimes transformed into new values and practices that they "appropriate" daily. In this process of constant interactions, they establish social roles, norms, and status, helping each other in shaping the new collectivity of which they are now part; solidarity and co-responsibility become core values that guide their everyday behaviors. When developing very strong social connections, individuals and families come to perceive that they owe each other mutual help. As A. L. Wright and Wolford's field research (2003) has demonstrated, while some tensions cannot be resolved and lead to ruptures within the MST, in other cases common suffering and friendship lead to mutual help and co- 
responsibility. Indeed, in Sarandi, Rio Grande do Sul, for instance, the Placotnik couple refused to move to another settlement, which would have meant leaving behind their "new family" as they called their friends of the occupation. They decided to settle on a very poor parcel. The rest of the newly created settlement felt it necessary to join forces and help them clean up the land so that they could cultivate it. Since then, the Placotniks have committed to celebrate the acquisition of the land every year by inviting the community to their home for a feast. This type of reciprocity and debt is voluntarily acquired rather than imposed; it is a sort of obligation or co-responsibility based on friendship, explicitly confronting dominant norms of utilitarianism, individualism, and interest maximization. In other words, acampados produce different ways of imagining life in community that reshape their behavior and ways of seeing their relationship with their environment.

Reflecting beyond their own local community, MST leaders and activists often insisted in various interviews and conversations on collective responsibility and the need for solidarity to pursue the struggle until every landless person can live a decent life:

The raison d'etre of the MST...is to struggle for the democratization of land...because of the historical problem of land concentration.... This means that land needs to be distributed...to those who want to work and live on the land....But we live in a society that is capitalist, that is individualist, and that privileges values we don't share.... Hence, there is permanent confrontation....In fact, this is the work of the MST. Who's part of the MST? The assentados and acampados. Because those who are assentados, it is because they have been acampados. And if he is acampado, it's because he's with the MST and therefore, he must continue with the MST [by participating in training, marches, and helping to support other occupations and settlements]. (interview, Porto Alegre, 2009)

This illustrates the tense relationships — but mutual influences - between landless participants seeking a piece of land, the leadership of the MST resisting the dominant social order and proposing an alternative based on socialism, and systemic forces with the power to impose strategies and constraints on everyday actors. The use of the auxiliary verb "he must continue" both validates a perception among MST leaders that structural constraints and unequal power relations of capitalist society require a continuing battle and commitment, and that landless participants owe this commitment to the MST as the latter helped them to access land.

The encampment also allows the emergence of an alternative economy that relies on everyone's skills, assets, relations, cooperation, and solidarity, without much direct interaction with the market economy. That alternative economy can either collapse or consolidate in the settlements. Different interviewees, analysts, and members of the MST have emphasized that the "cooperative is born in the encampment, and it has grown in the settlement" (MST coordinators, production sector, São Paulo and Porto Alegre, 2009). Indeed, they often insist on the crucial role of discussions and socialization, as well as "political and ideological training" that happen among acampados, where some participants become convinced, and help to convince others, of the need for and advantages of collective work and cooperation: that "this should be used and that it is the way" to go (interviews with MST coordinator, Porto Alegre, 2009; Copavi members, 2011; Coopan members, 2009, 2013). It is the birth and formation of their own norms that will translate into practices - once they grasp the reasons why they find themselves in their socioeconomic conditions of dispossession (Harvey, 2003). They are the ones who can promote, implement and consolidate the principles and practices in the settlements when they secure land titles, through different forms of cooperation. This is one early way through which a certain distinction emerges between two kinds of acampados: those who become MST activists, who support the broader sociopolitical project and values of the MST, including cooperation and solidarity to promote a more just and sustainable society for all; and those who take part in the occupation mostly 
to secure access to land and who tend to avoid further political involvement for various reasons, including because they have multiple family and production duties, or because they feel they have suffered enough and want to work the land they've been dreaming of for so long (Brenneisen, 2005; Vergara-Camus, 2009).

\section{On the role and multiple forms of cooperation and} cooperatives in the MST

As of February 2012, the MST claimed to have over 130 cooperatives (Previattelli, 2012) across the country, mostly concentrated in the southern states of Brazil, and between 450 and 500 associations also based on cooperation without having the legal characteristics of cooperatives (interview, São Paulo, July 2009). Very often in Southern Brazil, landless people come from individually owned farms rooted in family culture, where large families could not always divide the land between all (mostly) male children, so as to enable them to ensure their subsistence. Hence, after experiencing a number of failures and criticisms for trying to implement a Cuban-inspired form of cooperatives based on collective agricultural production and ownership of the land among landless families that are also rather marginal in other parts of the world (but see Bleil, 2012, for an in-dept analysis of the Copavi), the MST has decided that the members of each settlement should decide what forms of cooperation they want to adopt (interviews, São Paulo, Curitiba, Londrina 2009, 2011; Brenneisen, 2005; Gonçalves, 2008).

Among the various cooperative models, some are rooted at the local and regional levels, some are active at the level of a state or across a few states, while others operate on a national scale. Some focus on production or marketing, whereas others provide services to local and regional co-ops, like credit unions and co-ops providing technical training in agroecological production or cooperative management. Hence, in today's MST settlements, cooperation as a normative principle remains an essential value and feature of everyday life:

Cooperation can take various forms. There are associations and cooperation to buy machineries, for community tasks (mutirão) and collective mobilizations,... and regional cooperatives, which we have the most as forms of cooperation within the MST.... These co-ops work with many settlements...providing services, marketing, helping with training...Production cooperatives per se are a more advanced model of cooperation. They require a degree of training, of awareness ["conscientização," in Paulo Freire's (1970) sense of awakening of consciousness, through practice and dialogue], of availability and of willingness that is greatly superior to others. This is why it's not all families who want to work in such co-ops. Yet what is important is that, in one way or another, we have cooperation, for a tractor, to buy or sell...That there are forms of cooperation, this is what the movement promotes. (interview with MST leader, Porto Alegre, 2009, quoted in Massicotte \& Marques, 2012)

In this leader's view, to attain a high degree of cooperation in everyday practices, an equivalent degree of consciousness, political training, and individual commitment must be acquired; hence the production co-ops appear as the most demanding form of cooperation. In recent years, the "transformation and marketing cooperatives" have been the MST's most common way to promote cooperatives within the movement. In Rio Grande do Sul, Santa Catarina, and Paraná, for example, regional co-ops have emerged as a way to gain greater autonomy and self-determination (autogestão), increase the value of their products, and keep most revenue within the MST and its settlements, which allow reinvestment in the cooperatives (interviews, Nova Santa Rita, Porto Alegre, Curitiba, Lapa, and São Paulo, 2009; various settlements and encampments, Paraná, 2011). Marketing co-ops and agro-industries owned and managed by the MST are integrating market circuits and thus becoming more vulnerable to market fluctuations. Yet these same developments have allowed them to transform, diversify, and commercialize the agricultural production of many small farming households from different settlements, thus increasing their autonomy vis-à-vis conventional market 
forces and powerful intermediaries that were once imposing their rules and prices. An MST national coordinator in the production sector further emphasized:

One of our strategies is what you saw in our assentamentos, where people try to obtain as much autonomy as possible, from production until the agro-industrialization of all our products. So we put a lot of effort not on producing and selling only primary products to anybody in the market, but on setting up industries, in our own areas [MST settlements], to transform and sell not any products, but a product that carries an ideological weight...We don't want to just sell seeds, but produce and sell ecological seeds, produced in a correct way in terms of both ecological management and the human beings that are working and producing them [through, for example, the MST's own organic seed production, called Rede BioNatur]. This is a central element of our struggle, that we can gain this autonomy, which is not easy. (Interview, São Paulo, July 2009; also quoted in Massicotte \& Marques, 2012)

These practices represent a good example of the tensions and challenges co-ops face, and of how dominant norms become appropriated and reshaped by everyday actors to serve the collective goals and needs of the MST and its members. Embedded in a normative discourse, they become a sort of praxis of the solidarity economy. Although they still adopt a division of labor and produce in part for conventional supermarkets, where they need to be competitive to secure financial revenues, they have partly subverted the production process to make it fit into their own norms and priorities, including a permanent struggle that ultimately aims at dislodging capitalist markets to redistribute wealth more equitably in society. They thus continue to produce for selfsubsistence and for various political activities of the MST, such as national marches and congresses, and the yearly Jornada de Agroecologia event. The latter attracts thousands of local, national and international participants, where almost every delega- tion comes to celebrate, bringing and cooking their own food as well as exchanging seeds and ecological production techniques (field research notes and interviews, Londrina, June, 22-25, 2011; Massicotte, 2014).

Beyond the challenges faced by MST cooperatives as a result of the 2007-08 food crisis, a young female leader of the MST emphasized the recurrent fluctuations of food prices: "We cannot be romantics! It isn't sufficient to say that we'll make an allnice settlement and work in agroecology...Everybody needs an income to survive and if this financial return doesn't come, we cannot make it" (interview, São Paulo, 2009). This "market rationale" supporting transformation and marketing co-ops emerged from MST participants themselves who are well aware of, and do reassert, the influence of dominant economic discourses and material constraints imposed on them. However, they devise their own tactics by bringing together many smallscale producers, diversifying their production, avoiding intermediaries, and controlling almost every aspect of the food chain. In doing so, they reduce their dependence while increasing individual and collective revenues that remain within the settlements, thus strengthening the movement and its political agenda.

Yet, if compared with mega-agribusinesses, cooperatives continue to be "small enterprises" that face several difficulties, as this interviewee reminds us:

The consequences of the crisis for us are much bigger, because of the enormous competition on the market.... And we don't work with the intention of exploiting workers. So there is a different conception here. This is why for us, in our settlements, the impact is so important in a collective enterprise...In the conventional market, the one who lost the least is the fazendeiro (rural landowner), the agribusiness, because he has this strategy of exploitation and we don't....The size of our industries makes it very painful to absorb such attacks. In the case of milk, for a long period we could not sell, so the whole process became very fragile...We don't have the structure to support the 
crisis. There is the political force, the will to struggle... but the crisis is cruel in our settlements...And on top of that, the government finances and is concerned about the agribusiness, but it does not help small producers, it does not provide what it offers to agribusinesses. So, for us, it can be fatal. (interview, São Paulo, July 2009, our emphasis)

This interviewee highlights a "strategy of exploitation" that can be linked to how de Certeau (1990) defines strategy as the prevalent "way of doing" things. At the same time, she consciously says that this is not the "way we do things here." In other words, constrained by the dominant "strategy," they employ "tactics" in their own space. While they use dominant tools such as the market, they also refuse to use them in the same way: they transform the rules of the game through their "political force." They remain embedded in an individualist, consumerist, and capitalist society, yet their practices reject the market ideology and seek ways to implement alternative economic practices that sustain other norms and values, such as social and environmental justice and the common good. The MST also continually negotiates with the Brazilian state, securing various programs that guarantee, among other things, a stable monthly income for small producers beyond the market rule of supply and demand. For example, since 2009 a law has ensured that a minimum of 30 percent of the food purchased for a governmental program providing free school lunches comes from small family farms, many of them located in MST settlements, as we will see below. This program (Programa Nacional de Alimentação Escolar, PNAE) contributes to strengthening the socioeconomic viability, autonomy, and visibility of the cooperatives and the MST.

In parallel, one begins to see dilemmas and tensions faced by MST cooperatives. This economic model allows many peasants to collaborate in exciting and demanding collective endeavors, including transitioning toward diversified agroecological production and industrialization that have, in some cases, effectively increased their income and quality of life (see below). Agro- industries have simultaneously increased their degree of integration into the capitalist market economy, giving them better access to credit and debt, and in turn, making them more vulnerable to market competition and its boom and bust cycles. Nonetheless, it is crucial to highlight the opportunities that the very spaces and territories of encampments and settlements have opened up for numerous landless and marginalized households. What emerged from shared everyday experiences of organizing and resistance is a new way of imagining themselves as agents of sociopolitical change: a revamped sense of identity, dignity, and hope, and a sense that better lives are possible and in the making. Hence the political struggles of the MST are contributing to building alternative societies and economies. If what participants want in the short run is to be able to survive and live a decent life, this requires in the medium run changing state and economic policies; and in the long run, their struggle is to found a different society that unites around new values and different ways of being. The following section looks at two cooperatives to demonstrate how some experiences have nurtured solidarity and a collective identity that seem to be the secret ingredients for consolidating the co-ops as successful community economies. ${ }^{8}$

\section{Daily Life in MST Settlements and Cooperatives}

\section{The Cooperunião, Conquista na Fronteira Settlement, Santa Catarina}

In Santa Catarina, family farming employs 82 percent of all rural workers and produces 64 percent of the total agricultural output of the state (e.g., 73 percent of beans, 77 percent of corn, 90 percent of coffee (IBGE, 2013). Small producers are therefore significant economic players contributing to the

\footnotetext{
${ }^{8}$ Many landless workers come to the MST dreaming of owning their piece of land to guarantee the well-being of their family and descendants, break dependency linkages, and avoid the suffering they have known too well. Hence not every participant who benefits from land redistribution is equally committed to the longer-term collective fight for agrarian reform and to continually respond positively to the multiple demands of the MST leadership to pursue socialist ideals (Diniz \& Gilbert, 2013).
} 
well-being of the people. It is in the western region of that Brazilian state that, after an "encampment time" spanning from two to five years, 60 landless families obtained the legalization of the Conquista na Fronteira encampment in June 1988. The new settlement covers 2,965 acres (1,200 hectares) of land. The cooperative Cooperunião was launched in October 1990 and remains among the few MST co-ops that are fully cooperative, commercializing mostly conventional poultry and milk, but producing everything that is necessary to ensure subsistence and good living conditions for each of the 60 households:

All the basic food items come from the settlement. People can buy if they want, like white sugar, because we only produce brown sugar internally. But...in general, people don't go to the store....In my mother's home...you cannot get them [plastic bags] as you don't go to the supermarket; you produce. (interview, MST member, June 2009)

After more than two decades, all the community's families have very decent homes, and like many other MST settlements, they have a health clinic, a cultural center, daycare services, and an elementary school with its own curriculum, which includes political, cultural, socioeconomic, and environmental justice components. These socioeconomic resources also become social and political vehicles through which co-op associates try to institute their own norms and practices on a daily basis.

As mentioned earlier, all the settled families are involved in some aspects of the agricultural co-op's work as associados (associates). They share the land, tools, production, and income. They also collectively make decisions regarding all aspects of community life ${ }^{9}$ and share the responsibilities for their successes and failures (interview, São Paulo, June 2009). When the MST-affiliated families created the Cooperunião, they followed the usual

\footnotetext{
${ }^{9}$ When members have special needs for specialized training or medical treatment unavailable within the settlement, for instance, the general assembly decides whether they can obtain it.
}

cooperative organizing structure with a general assembly as the main body for decision-making. However, they added management elements characteristic of other MST settlements, organizing in "núcleos de base" (small committees) of about 10 households, in various sectors of production (cattle raising, milk, vegetables, management, market sales, etc.), as well as key sectors for organizing collective life (sport and leisure, education, infrastructure, health, etc.). In their search for greater autonomy and democratic participation, each sector and coop member is responsible for implementing the collective decisions that emerge from the assembly and reporting back on progress and difficulties. Regularly attended by about 70 percent of all associates, the assembly also elects those in charge of the various productive activities and responsibilities of the co-op by secret ballot for a three-year term. Regular elections encourage a rotation of tasks and responsibilities. When associates assume difficult tasks, they know that this is for a limited time. It means that they have to transmit their knowledge and techniques to others, a "way of doing" promoted by the MST with its emphasis on ongoing education and training, in schools and on the ground, which some refer to as "learning by doing," through practices and exchanges (interviews and discussions, Paraná, São Paulo, Rio Grande do Sul, 2009, 2011; Massicotte, 2014). This is an effective way of avoiding dependency on a single person or leader to perform certain tasks. Such organizing principles also contribute to building capacity, knowledge, and leadership of the community as a whole, and encourage reciprocity and mutual learning.

Nonetheless, it is important to highlight that during the first years of the settlement, there were tensions between settlers who formed two distinct groups and separated the land between them, with an equivalent of 50 acres (20 hectares) per family (Frente de Prensa, 2007; Vieitezi \& Dal Ri, 2003). Whereas the group supported by the municipality was not convinced by the collective model, mostly because of family farming traditions, the MST families pushed for the creation of a production cooperative. Among landless workers who were politicized through MST occupations and struggles, self-management (autogestão) and collective work 
seemed more appropriate to gain leverage and be more effective. As an organizing norm, the emphasis on collective work defies the dominant model of agro-industrial monoculture. Discussing work relationships, tensions, and challenges that the Cooperunião associates face constantly, Carla Tatiane Guindani (2013, p. 3) explains:

Workers are owners of the means of production and the work force is collective...to the extent that they can develop a collective consciousness, work stops being a painful necessity and becomes a pleasant duty, because they don't work for the benefit of the boss but for the benefit of the collective.

As such, and despite remaining frustrations among co-op workers, the everyday experiences of members of the new settlement clearly reshaped normative discourses, as well as their political economic preferences, rather than being shaped only by neoliberalism.

Like five other co-ops in Santa Catarina, the Cooperunião sells under an MST brand, "Terra Viva." With the advice of agronomists, they have chosen to produce fish as a complement to poultry production because it allows them to use parts of the chicken to feed the fish; this combined method greatly reduces what is usually considered waste to be discarded in the environment. Here, they have found holistic ways to farm that integrate the lifecycle of the products, from the beginning to the end of the food chain (interview, MST member, June 2009). The Cooperunião has expanded to the point of producing an average of 660 to 790 U.S. gallons (2,500 to 3,000 liters) of milk per day, transformed and commercialized by another MST co-op in the region. They also recently doubled their slaughtering capacity in their own abattoir to about 2,000 chickens per hour, some of which come from other family producers in the region (interview 2009; email exchange, 24 Feb. 2014; Prensa de Frente, 2007). While this larger-scale production allows them to be more competitive in the regional market, it also means that they rely mostly on conventional methods with greater environmental impact, and that market fluctuations are felt more directly by the families.
The subsistence provisioning and revenue of the co-op associates remain partly monetized and partly in-kind products, following the number of hours worked but also taking into account the needs of each household. Based on a gendered division of labor, men normally work 8 hours per day, 5 days a week, whereas women work 4 hours or more for the co-op and 4 hours for household responsibilities (caring for children, elders, family garden, etc.). Despite formal recognition of these crucial tasks that are still largely women's responsibilities, they are not calculated in the number of hours worked for the co-op. On the other hand, hours spent in external meetings and MST activities such as marches, training, and mobilization count toward the co-op income distribution. Hence the notions of justice and solidarity, central to the MST and the Cooperunião's vision of a better society, remain problematic in terms of gender justice.

The production surpluses, which are very significant in this case, are commercialized and sold in farmers' and conventional markets across the state of Santa Catarina and in four other Brazilian states. Other key outlets for the Cooperunião are federal, state, and municipal social assistance programs such as the Food Acquisition Program (Programa de Aquisição de Alimentos, PAA) and the previously mentioned PNAE. These programs work in parallel to the capitalist market as they guarantee a stable revenue at a fair price specifically targeted at family producers, and they provide fresh and healthy food aiming at ensuring food security for all through, for instance, school lunches, community kitchens, and basic food baskets. In 2011 the Cooperunião participated in the PNAE, providing 19,080 lb. (8,655 kilos) of frozen chicken to public schools and received in return $\mathrm{R} \$ 31,050^{10}$ (Intituto Nacional de Colonização e Reforma Agrária [INCRA], 2012). In 2013, the co-op sold 97 million pounds (44 million kilos) of chicken to the PAA program, a program that will expand in 2014 at the municipal level and will include beef, vegetables, and grains (email exchange, MST member, February 23, 2014).

\footnotetext{
${ }^{10}$ On June 29, 2012, the conversion rate was $\mathrm{R} \$ 1=\mathrm{US} \$ 0.50$, so $\mathrm{R} \$ 31,010=\mathrm{US} \$ 15,525$.
} 
Hence the cooperative organizes the settlement around the sociopolitical goals of the MST and the daily needs of the community (personal, family, work relationships, security, services, cultural activities, etc.), as well as around its economic activities. In Polanyi's words, they are re-embedding the economy into the political and cultural sphere of the community. Through the activities of the co-op, one can however witness (1) how gender biases persist and (2) how various forms of paid and calculated labor (e.g., food production, transformation, marketing, administration, MST and co-op meetings and militancy) and unpaid and uncalculated labor (e.g., caring for elders, children, sick people, and family plots) intermingles with other spaces of daily life, thereby multiplying and diversifying social interactions among settlers. In most cases and despite significant efforts by the MST, the machista culture continues to assign traditional roles to men and women, thus reproducing gender roles and power structures, attributing more value and monetized income to certain types of work. Nonetheless, co-ops tend to divide revenues among all associates working for the co-ops, including women and young adults, either equally or based on the number of hours worked. Some co-ops are considering, or have already established, that a greater value should be attributed to more complex or demanding tasks that only some members are willing or able to accomplish. Paid and unpaid work are both crucial to strengthen community life and maintain good relationships since people have to interact and collaborate continually. In such recently created community and territory, one witnesses the emergence of a system of reciprocity, based on obligations and coresponsibilities that bind members together on a voluntary basis.

This co-op is known internationally for its economic success, but it is also a very interesting example of collective autonomy and democratic self-governance from below. As one MST interviewee (2009) explained, the associates have "learned to cooperate through their daily practices" in order to organize daily life, production, and social reproduction of the broader community. Nonetheless, this case points out some of the numerous challenges that co-ops continue to face, as they remain partly dependent on the capitalist market economy and governmental programs. The other major challenge relates to their ecological impact as the expanding size of the production and agro-industries makes it increasingly difficult for the co-op to transition toward more agroecological forms of production.

\section{The Coopan, Capela settlement, Rio Grande do Sul} In the state of Rio Grande do Sul - where the Labour Party (PT, for its Portuguese acronym) was strong at the end of the 1980s in Porto Alegre, and the region in which progressive initiatives such as the participatory budget and the first editions of the World Social Forum have been implemented - the MST has been criminalized, especially under the leadership of state governor Yeda Crusius (PSDB political party, in office 2007-2011). Negative media coverage of the MST is not new, but recently government officials, mainstream media and business leaders have increased their attacks, for example by refusing to pay for and by closing seven itinerary schools in MST encampments in the state in February 2009 (interviews Coopan members, 2009, 2013; Scalabrin, 2009). In this context, the successful experiences of the MST have been essential for demonstrating the benefits for society and for rural farming families in the context of a limited process of land distribution. The MST claims that among the settled families who gained access to land in 250 settlements of this southernmost state of Brazil, 24 settlements are producing " 3,300 hectares [8,154 acres] of organic rice" and were planning to get 280 thousand bags for the harvest year 2012-13 (interview conducted by Dan F. Marques with a Coopan member, June 18, 2013). This organic rice will not only benefit upper- and middle-class households but will also be redistributed to public schools and included in food baskets for poor families through CONAB and various governmental programs (Globo.com, 2011). ${ }^{11}$ As mentioned in the intro-

\footnotetext{
${ }^{11}$ CONAB stands for the Companbia Nacional de Abastecimento, or National Food Supply Agency. This public company was created by the federal government in 1990 to work in the agribusiness sector and to ensure regularity of the food supply. It monitors agricultural production and stores food stocks, and
} 
duction, the Coopan is one of the MST's oldest coops producing agroecological rice in Rio Grande do Sul, near Porto Alegre (Map 1).

When it was created in 1994, 52 families joined the co-op (Lanner, 2011). These MST families had chosen, during their encampment time, to stick together until they could get a large enough parcel of land for all of them to work collectively in order to gain more social and economic benefits. From the start, some families chose to work their plots individually. Over the years, others left the Coopan for various reasons, including the fact that some individuals felt it was too complicated to constantly make decisions and work collectively, or because they hoped to be more profitable outside of the coop (interviews, 2009, 2013). As of 2013, the Coopan includes 30 families and 61 co-op workers who have opted for a diversified model of production in an area covering 1,430 acres (580 ha) of the settlement (Lanner, 2011; interview conducted by Dan F. Marques). Households of the agrovila (small rural villages where co-op members have lined up their homes close to the co-op installations, including an abattoir, a cafeteria, and a daycare) grow some vegetables, herbs, fruit trees, and and/or flowers for subsistence and to embellish their environment. Having benefitted from the housing program created under the PT government of Lula da Silva, most houses are spacious and comfortable. They have electricity, which is essential for the coop industries discussed below. Many homes also have Brazilian-style barbecues, and some even have a garage and a car or motorcycle, symbols of higher social status in Brazilian culture (author's observation and interviews, Coopan, 2009).

In order to generate permanent, monthly revenue, co-op members rely mostly on pork (a longstanding family practice for many), dairy, and organic rice production (16 thousand bags of organic rice per year produced by the co-op and another 64 thousand bags processed by the co-op but coming from other producers in the Capela and other surrounding settlements). Since 1997,

it is also in charge of providing income to small rural producers as well as food to poor households and social sectors (e.g., public schools, hospitals) through various public programs and policies.
Coopan has controlled the full production process, and today around 3,000 pigs are sent to the co-op's abattoir each month (about 20 percent from the Coopan), while also providing hog slaughtering services for other producers of the region (Lanner, 2011; interview, 2013). Lanner (2011) highlights the polluting aspects of this production, with an estimated 1,336 U.S. gallons (5,058 liters) of liquid waste per day, plus the abattoir's own waste. Yet pork remains the main source of revenue for the Coopan, which highlights the paradox and multiple dilemmas with which co-op associates are dealing. They are presently seeking ways to reduce their environmental impact by producing biofertilizers but also, as suggested by Lanner's study, by investigating the possibility of buying biodigestors, for example.

Over the years, the co-op has developed its own agro-industries and marketing circuits for pork and agroecological rice to "create more jobs for their children," to "avoid exploitation," and to gain "greater autonomy and control" over fluctuating markets (interview, Porto Alegre, 2009). These products are sold in 30 regional and local farmers' markets in the metropolitan area of Porto Alegre. At first, the co-op produced rice and milk following conventional methods, using the usual package of agro-toxins. However, they have decided to make the "transition toward agroecology" for rice, after realizing that traditional methods were ecologically damaging, as well as making them "less healthy and poorer," because of the dependency on, and the price of, these "technological packages" (interview, 2009). The valueadded for agroecological products was also part of the equation. Emerson Giacomelli, one of the five directors of the settlement and ex-president of the Cooperativa Central dos Assentamentos do Rio Grande do Sul (Central Cooperative of the Settlements of the State of Rio Grande do Sul, or Coceargs), explains that when MST settlements opted for agroecological rice production, "conventional producers thought we were crazy. Today, they want to know how we make benefits in the middle of the crisis." Giacomelli maintains that this political decision is why even if organic producers "entered the crisis, they did not go bankrupt" like so many conventional producers, because they 
have lower cost of production $(\mathrm{R} \$ 15$ per bag compared to $\mathrm{R} \$ 28$ for conventional) while seeking to maintain affordable prices for consumers (Estadão/Blogs, 2011). However, the Coopan had to stop its dairy production early in 2012 because tuberculosis had decimated its dairy cow herd. It is hoping to resume this activity (email exchanges with Coopan member, 2011; interview with Coopan member, conducted by Dan F. Marques, May 2013).

The co-op sustains all of the associates' families as well as helping to strengthen the MST economically and symbolically by providing a concrete example of the capacity of landless people to organize themselves and produce quality food. Moreover, as attested to by Zara Lubing Schroeter, vice mayor of the nearby town of Nova Santa Rita during the 12th anniversary of the Coopan in 2006, co-op members are contributing to the regional economy by generating income, expanding the circulation of products and money, and promoting education and cultural activities:

The benefits are not felt only by assentados, but by the local population as well....The MST settlement only brings benefits. These are people who work and contribute to our economy.... Here we have people (landless) that were born believing in an egalitarian country and today, they are concretizing this dream. We have a lot to celebrate. (quoted in MST article, 2006)

This is a concrete example of everyday practices based on alternative discourses directly influencing the socioeconomic development of communities beyond their own. Public authorities recognize their positive role in improving the dynamism and social structures of the region.

A founding member of the Coopan, Etelvino Romanzin, constructively synthesized the multiple and transformative impacts that collective work and everyday life in cooperatives, as well as in many encampments and settlements, have for MST participants:

The cooperative opens up more opportunities for progress and social and economic development of the settlement.... It is a new experience of living collectively in harmony (experiência nova de convivência no coletivo)....Working together, we are able to get better prices for our products and we develop ourselves as citizens. (MST article, 2006, emphasis added)

This "new experience of collective living" that "develops" the co-op members as "citizens" is an extremely important process for their political imagining. Indeed, it is through everyday interactions based on solidarity and mutual help that the members elaborate their sense of duty and belonging to the community. They become aware of the importance of co-responsibility in the development of both their own individuality and of collective well-being.

Beyond significant material gains for MST participants, Emerson Giacomelli insists on the "human benefits" and on the fact that the decisions to industrialize and develop their own marketing strategy came "from small producers themselves," as a way to face the crisis and to increase the value of their production:

Our conquest is more buman than it is material. The settlement and the Coopan bring dignity to the landless; they allowed these people to walk with their heads up high and to acquire their rights. They now have an employment and leisure activities. (quoted in MST, 2006; emphasis added)

This testimony is revealing of what they consider to be their main achievements. Of course, as noted earlier, they must produce for their subsistence and therefore, to a certain extent, play by market rules. However, as this MST coordinator highlights, what they "conquer" is "more human than material." They learn the importance of working together, as a community, for a common goal, which also involves some personal sacrifices for an ideal greater than themselves.

\section{Conclusion}

Some theoretical reflections include how ways of imagining life in rural communities are emerging at 
the margins of today's dominant market economy, and how the manner in which participants think of themselves and their role within such communities interacts with and is shaped by their everyday practices in organizing and struggling for community economies and societies. The work of de Certeau is useful for understanding to what extent and in what ways MST encampments and settlements are opening spaces for imagining and experimenting with different modes of production and community. This paper discussed the tactics through which less powerful communities appropriate and distort dominant norms and institutions, such as consumerism, individualism, and market capitalism, within the limits of the possible (Braudel, 1981), and create alternative forms of solidarity economies. By explicitly looking for alternative values and practices emerging at the margins of today's dominant institutions (Gibson-Graham, 2006; de Sousa Santos, 2006), including modern industrial monoculture, I was able to make visible the experiences of rural communities that, despite and in part because of harsh socioeconomic conditions, have succeeded in implementing more participatory, just, and sustainable practices.

When discussing the opportunities and limits of promoting alternative models of agriculture based on agroecological principles in Brazil, for example, one Coopan interviewee noted that agroecology is nurturing a sense of community toward greater participation, as well as social and environmental justice. For him, the battle remains at the level of ideas and perceptions, which require constant efforts, but also socioeconomic and political support. He argues that people are becoming more aware of the "need to diversify food production, to preserve the environment... and the result is that we have more consumers [for organic products]." Yet he specifies that it is still insufficient when considering how few households in fact translate such awareness into concrete practices (interview, MST member, Porto Alegre, 2009). Moreover, while some federal programs exist for small producers engaging in diversified, more ecological farming, these are quite negligible in comparison to policies and resources supporting large-scale agribusinesses, thus highlighting the material and structural constraints that resistance forces face when seeking to implement more just and ecological practices. As another MST interviewee insisted, it is crucial that "the government provide an effective technical assistance program, as well as more incentives for rural youth to continue to work the land and to encourage small-scale, organic production" (email exchanges, February 23, 2014). Indeed, as the two co-op cases above illustrate, when conventional practices are in place, allowing significant productivity and revenues, it is difficult to transition toward more agroecological practices, especially in more challenging sectors such as poultry and pork, without greater governmental supports and commitment to small-scale producers.

At the empirical level, my field research and document analyses have shown that, in practice, there are many forms of cooperation and solidarity within MST camps and settlements, beyond the formal structure of cooperatives usually associated with the solidarity economy. When MST participants did not wish to work the land collectively or take part in a formal cooperative where decisions are made by all co-op associates, it did not hinder their desire for devising other forms of mutual help. Hence, what counts as cooperation and the solidarity economy in Brazil and in other parts of the world may benefit from a more flexible definition in order to learn from a wider range of experiences. I believe that this case study research points out the need for further research on the various principles, and spatial and temporal conditions, that tend to foster greater solidarity and mutual help among individuals and communities. Deepening our understanding of such processes would be useful not only in the rural south but also in the global north, where most analyses of the social and solidarity economy tend to focus on the procedural and economic efficiency of co-ops, and much less on the sociopolitical imaginaries, values, and norms that can foster and sustain greater cooperation.

In this paper, I also noted how leadership, time, and space are crucial factors to study; they can sustain or impede greater solidarity and the consolidation of a community economy. The occupation and encampment experiences - which open up a specific space as well as a significant time period where individuals and families are forced to work together and build trust for their own security and 
survival - highlight some of the conditions that contributed to the emergence and consolidation of alternative norms and practices, including coresponsibility, cooperation, participation, collective autonomy, and governance. In this respect, the type of leaders who emerged in each community and agricultural cooperative can make a crucial difference between success and failure, as well as the perception and actual form of support received by allies and movements, in this case the Brazilian Landless Rural Workers Movement. Of course, in North America or Europe, the contexts are very different. Nonetheless, it remains relevant to take into account conditions that contributed to successful experiences in rural Brazil and to explore if they are present in other contexts, and if they could be adapted by other communities sharing similar sociopolitical projects.

Finally, and although this was not explicitly stated by interviewees, it is important to note that there remains a long way to go before successful experiences, such as those of the two co-ops studied here, can be implemented on a larger scale and contribute to consolidating a greater number of alternative economic models, based on solidarity, reciprocity, and greater social and environmental justice. Even the two "successful" cooperatives described in this study face important challenges and need to struggle to maintain their membership, especially among the younger generations (email exchange, February 23, 2014). The key principles that underpin such initiatives are constantly under pressure in that they are embedded in a competitive and globalizing environment marked by gender, racial, ecological, ideological, and economic biases. Nonetheless, the MST's steady efforts and ability to support land occupations and to pressure governments have led to successful experiences of agricultural production and reproduction, inspiring other movements and communities. In Rio Grande do Sul, for example, the MST contributed to state officials' decision to settle the remaining 186 families who still lived in encampments across the state as of May 2013 (interview by Dan F. Marques with a COOPAN member, May 2013). The struggle therefore continues as MST activists have always maintained that their struggle is not only for access to land but also for greater justice for all, which is pursued through agricultural cooperatives among other tactics and strategies, despite and in parallel with the advance of agribusinesses locally and on a global scale.

The United Nations has designated 2014 as the International Year of Family Farming, recognizing its contribution to fighting the environmental crisis and fostering greater food sovereignty. The World Economic Forum, the Food and Agriculture Organization of the U.N. (FAO), and the U.N. Conference on Trade and Development (UNCTAD) also acknowledge the value of smallscale, agroecological and family farming to fight rural poverty. Further analyses highlighting the strategies, tactics, political imaginaries, and community dynamics, as well as (re)productive and mobilizing capacities of rural communities, are needed to turn these mostly symbolic recognitions into concrete actions. They can contribute to a better understanding of the obstacles, needs, and opportunities that small producers still face while making such initiatives more visible and credible. They should also deepen our understanding of the necessary changes to promote greater social and environmental justice, anchored in specific cultural and sociopolitical contexts, that are already working to build alternative community economies.

\section{Acknowledgments}

Thanks to workshop participants (Annette Desmarais, Alex Latta, Hannah Wittman, and Erik Olin Wright), José Lopez, and anonymous reviewers for their useful suggestions. I want to acknowledge Dan Marques's insights and work as research assistant, as well as those of Tiarajú D'Andrea, Doctor of Sociology, Universidade de São Paulo, and Eugénie Boudreau, MA candidate, University of Ottawa. I particularly want to thank all the interviewees who shared their time and knowledge with me. Finally, this article benefitted from the financial support of the SSHRC and helpful editing from Dana Hayward, Stephen Brown, and Claude Denis. 


\section{References}

Altieri, M. A., \& Toledo, V. M. (2011). The agroecological revolution in Latin America: Rescuing nature, ensuring food sovereignty and empowering peasants. Journal of Peasant Studies, 38(3), 587-612. http://dx.doi.org/10.1080/03066150. 2011.582947

Bleil, S. (2012). Vie et luttes des Sans Terre au sud du Brésil: Une occupation au Paraná. Paris: Les Editions Karthala.

Branford, S., \& Rocha, J., (2002). Cutting the wire: The story of the landless movement in Brazil. London: Latin American Bureau.

Braudel, F. (1981). Civilization and capitalism, 15 1 th 18 th Centuries: The structures of everyday life: The limits of the possible (Vol. I). New York: Harper \& Row.

Brenneisen, E. (2005). O MST e os assentamentos rurais no oeste do Paraná: Encontros e desencontros na luta pela terra [The landless rural movement and the settlements in the west of Paraná: Agreements and disagreements over the struggle for land]. Estudos Sociedade e Agricultura, 12(1), 128-163. Retrieved from http://socialsciences.scielo.org/ Coraggio, J.L. (2011). Economía social y solidaria: El trabajo antes que el capital. Alberto Arroyo \& Esperanza Martinez, eds. Facultad Latinoamericana de Ciencias Sociales Sede Ecuador (FLASCO) \& Ediciones Abya-Yala, Quito, Ecuador. PDF online book, retrieved from http://www.coraggioeconomia. org/jlc/archivos $\% 20$ para $\% 20$ descargar/Econom $\%$ C3\%ADa $\% 20$ social $\% 20 \mathrm{y} \% 20$ solidaria. $\% 20 \mathrm{EL} \% 20 \mathrm{t}$ rabajo $\% 20$ antes $\% 20$ que $\% 20$ el $\% 20$ capital.pdf

de Certeau, M. (1990). L'invention du quotidian, I: Arts de faire. Paris: Editions Gallimard.

de Sousa Santos, B. (Ed.). (2006). Another production is possible: Beyond the capitalist canon. New York:Verso Books.

de Sousa Santos, B. (2010). Le Forum social mondial et le renouvellement de la gauche mondiale. In P. Beaudet, R. Canet, \& M.-J. Massicotte (Eds.), L'altermondialisme: Forums sociaux, résistances et nouvelle culture politique (pp. 58-78). Montréal: Écosociété.

Diniz, A. S., \& Gilbert, B. (2013). Socialist values and cooperation in Brazil's Landless Rural Workers' Movement. Latin American Perspectives, 40(4), 19-34. http://dx.doi.org/10.1177/0094582X13484290

Escobar, A. (2004). Beyond the Third World: Imperial globality, global coloniality and anti-globalisation social movements. Third World Quarterly, 25(1), 207-230. http://dx.doi.org/10.1080/0143659042000185417

Estadão/Blogs. (2011, August 30). Arroz sem crise [Web log post]. Retrieved from http://blogs.estadao.com.br/organicos/2011/08/ 30/arroz-sem-crise/

Fiorentin, M. (2006). MST e desenvolvimento local: Uma experiencia do assentamento Conquista na Fronteira/SC (Unpublished master's thesis). Department of Geography, Universidade Federal do Rio Grande do Sul, Porto Alegre, Brazil.

Freire, P. (1970). Pedagogy of the oppressed. New York: Herder \& Herder.

Gaiger, L. I. (2007). Nouvelles formes de production non capitalistes au Brésil: Sens et faisabilité. Revue Tiers Monde, 190(2), 309-324. http://dx.doi.org/10.3917/rtm.190.0309

Gibson-Graham, J. K. (2006). A postcapitalist politics. Minneapolis, Minnesota: University of Minnesota Press.

Gliessman, S. R. (2001). Agroecosystem sustainability: Developing practical strategies. Boca Raton, Florida: CRC Press.

Globo.com. (2011, April 22). Cultivo do arroz orgânico faz sucesso em assentamentos do RS. Globo Rural. Retrieved from http://g1.globo.com/economia/ agronegocios/noticia/2011/04/cultivo-do-arrozorganico-faz-sucesso-em-assentamentos-do-rs.html

Gonçalves, S. (2008). A luta na terra: Os assentamentos do MST e o desenvolvimento do município de Querência do Norte-PR. Presidente Prudente, Brazil: Author.

Guindani, C. T. (2013). Contribuições da economia e gestão para o estudo de caso dos jovens do assentamento conquista na fronteira (Unpublished paper). Itacorubi, Santa Catarina, Brazil: Universidade Federal de Santa Catarina, Centro de Ciências Agrárias.

Gutiérrez Escobar, L. M. (2011). El proyecto de soberanía alimentaria: Construyendo otras economías para el buen vivir. Otra Economía, 5(8), 59-72. http://dx.doi.org/10.4013/otra.2011.58.05

Hadich, C. \& Tardin, J. M. (2009). Escola Latino Americana de agroecologia: Experiências camponesas de agroecologia (Unpublished report on file with the author).

Harvey, D. (2003). The new imperialism. Oxford: Oxford University Press. 
Icaza, R., \& Vázquez, R. (2013). Social struggles as epistemic struggles. Development and Change, 44(3), 683-704. http://dx.doi.org/10.1111/dech.12039

Instituto Brasileiro de Geografia e Estatística [IBGE]. (2013). Censo 2006 and 2010. Retrieved from http://www.ibge.gov.br/

International Fund for Agricultural Development [IFAD]. (n.d.). Rural poverty in Brazil. Retrieved December 5, 2013, from http://www.ruralpovertyportal.org/fr/country/ home/tags/brazil\#

Intituto Nacional de Colonização e Reforma Agrária [INCRA]. (2012). SC: Fornecimento de produtos para alimentação escolar fortalece economia de assentamentos. Retrieved from http://www.incra.gov.br

Konder Comparato, B. (2004). L'action politique des sansterre au Brésil. Paris: Editions L'Harmattan.

Landless Rural Workers Movement [MST]. (2006, May 9). Coopan é exemplo de que a Reforma Agrária dá certo. Retrieved from http://www.mst.org.br/node/2218

Landless Rural Workers Movement [MST]. (2013, April 25). Vídeo: A reforma agrária é viável e necessária para o Brasil [Video file]. Retrieved from http://www.mst.org.br/node/14747

Lanner, A. J. (2011). A cooperativa de produção agropecuária Nova Santa Rita LTDA. (COOPAN) do assentamento Capela, Nova Santa Rita (RS): Questões da actividade suinicola (Master's thesis). Universidade Federal do Rio Grande do Sul, Porto Alegre, Brazil. Retrieved from http://hdl.handle.net/10183/38175

Lemaître, A., \& Helmsing, A. H. J. (2012). Solidarity economy in Brazil: Movement, discourse and practice analysis through a Polanyian understanding of the economy. Journal of International Development, 24(6), 745-762. http://dx.doi.org/10.1002/jid.2865

Marañón, B., \& López, D. (2010). Economía solidaria y sociedad alternativa en América Latina: Hacia una agenda de investigación desde la descolonialidad. Alternativas, 67(5), pp. 1-12. Retrieved from http://alainet.org/images/alts67.pdf

Massicotte, M.-J. (2014). Feminist political ecology and La Vía Campesina's struggle for food sovereignty through the experience of the Escola LatinoAmericana de Agroecologia (ELAA). In P. Andrée,
J. Ayres, M. J. Bosia, \& M.-J. Massicotte (Eds.), Globalization and food sovereignty: Global and local change in the new politics of food (pp. 255-287). Toronto: University of Toronto Press.

Massicotte, M.-J., \& Marques, D. F. (2012). Processus de radicalisation et radicalité au quotidien: Discours et pratiques des communautés rurales au Brésil. Lien Social et Politiques, 68, 167-191. http://dx.doi.org/10.7202/1014810ar

McMichael, P. (2004). Development and social change: $A$ global perspective ( $3^{\text {rd }}$ Ed.). Thousand Oaks, California: Pine Forge Press.

Mourão Vieira, F. (2005). Coerência e aderência da economia solidária: Um estudo de caso dos coletivos de produção do MST em Mato Grosso do Sul (Doctoral dissertation). Universidade de São Paulo, São Paulo. Retrieved from Biblioteca Digital website: http://www.teses.usp.br/teses/disponiveis/12/121 38/tde-28082006-155039/pt-br.php

Polanyi, K. (1944). The great transformation: The political and economic origins of our time. Boston, Massachusetts: Beacon Press.

Prensa de Frente. (2007, July 17). Conquista na Fronteira, en Santa Catarina: Cómo se organiza internamente un asentamiento. Retrieved March 2, 2012, from http://www.prensadefrente.org/pdfb2/ index.php/a/2007/07/17/p3021 [no longer online]

Previattelli, J. (2012). 2012: o Ano Internacional das Cooperativas. Retrieved from http://www.mst. org.br/2012-o-Ano-Internacional-das-Cooperativas

Quijano, A. (2008). "Solidaridad" y capitalismo colonial/moderno. In Otra Economía: Revista Latinoamericana de Economía Social y Solidaria, 2(2), 12-16. Available online: http://www.economia solidaria.org/files/Revista_RILESS_2.pdf

Rangel Loera, N. (2010). 'Encampment time': An anthropological analysis of the land occupations in Brazil. Journal of Peasant Studies, 37(2), 285-318. http://dx.doi.org/10.1080/03066151003594930

Rist, G. (2008). The bistory of development: From western origins to global faith ( $3^{\text {rd }} \mathrm{Ed}$.). New York: Zed Books.

Russo, O. (2012). Brésil: L'ancien et le nouveau latifundium. Retrieved from À l'encontre website: http://alencontre.org/ameriques/amelat/bresil/ bresil-lancien-et-le-nouveau-latifundium.html \#more-8696 
Ministério do Desenvolvimento Agrário (MDA) (2010). Agricultura familiar: MDA libera R \$ 1,5 bilhão do plano SAFRA 2010/11 a SC. Retrieved from MDA: http://mda.gov.br/portalmda/noticias/sc-mdalibera-r-15-bilhão-do-plano-safra-da-agriculturafamiliar

Scalabrin, L. (2009, February 18). MP e Governo Yeda voltam a criminalizar MST. Retrieved from http://www.mst.org.br/node/6489

Scott, J. C. (1985). Weapons of the weak: Everyday forms of peasant resistance. New Haven, Connecticut: Yale University Press.

Souza da Silva, A., \& Feijó Fagundes, L. (2011, May). Agroecologia e educação do campo. Boletim DATALUTA, 1-13. Retrieved from the Universidade Estadual Paulista (UNESP) Núcleo de Estudos, Pesquisas e Projetos de Reforma Agrária (NERA) website: http://www2.fct.unesp.br/nera/artigodomes.php

Stédile, J. P., \& Fernandes, B. M. (1999/2005). Brava gente: A trajetória do MST e a luta pela terra no Brasil (3rd impression). São Paulo: Editora Fundação Perseu Abramo.
Vergara-Camus, L. (2009). The politics of the MST: Autonomous rural communities, the state, and electoral politics. Latin American Perspectives 36(4), 178-191. http://dx.doi.org/10.1177/0094582X09338608

Vieitezi, C. G., \& Dal Ri, N. M. (2003). Formação da cooperativa de produção agropecuária União do Oeste Ltda: Cooperunião [Formation of the cooperative for crops and animals raising production União do Oeste Ltda: Cooperunião]. Revista ORG \& DEMO 4, 119-124. Retrieved from http://www2.marilia.unesp.br/revistas/index.php/ orgdemo/article/viewFile/434/333

Wittman, H. (2007). Planting peace: MST co-operatives and agrarian justice in Brazil. In J. Emmanuel \& I. MacPherson (Eds.), Co-operatives and the pursuit of peace (pp. 121-146). Victoria, B.C.: New Rochdale Press and BCICS.

Wright, A. L., \& Wolford, W. (2003). To inherit the earth: The landless movement and the struggle for a new Brazil. Oakland, California: Food First Books.

Wright, E. O. (2010). Envisioning real utopias. London: Verso Books. 